\title{
Audit Committee Competence and Earnings Management in Europe
}

\author{
César Zarza Herranz ${ }^{a}$, Nuria Reguera Alvarado ${ }^{b}$, Félix J. López Iturriaga \\ a)Departamento de Economía y Dirección de Empresas, Facultad de Ciencias Económicas, Empresariales y Turismo, Universidad de Alcalá de Henares, SPAIN \\ b) Departamento de Contabilidad y Economía de la Empresa, Facultad de Ciencias Económicas y Empresariales, Universidad de Sevilla, SPAIN. \\ c) Departamento de Economía Financiera y Contabilidad, Facultad de Ciencias Económicas y Empresariales, Universidad de Valladolid, SPAIN.
}

${ }^{c}$ Corresponding author.

E-mail address: flopez@eco.uva.es

\section{A R T I C LE INFO}

\section{Article history:}

Received 25 June 2019

Accepted 28 July 2020

Available online 1 January 2022

\section{JEL classification:}

M42

G34

\section{Keywords:}

Accounting expertise

Audit committee

Corporate governance

Earnings management

Financial expertise

\section{A B S T R A C T}

This study analyses the association between the competence of audit committee members and earnings management in a sample of 142 non-financial firms from France, Germany, Italy, Spain, and the United Kingdom over the 2006-2013 period. We measure members' competence through their dedication and expertise. We find that outside directorships have a dual effect, such that a balanced level of dedication to the audit committee (roughly two outside directorships) reduces earnings management. We examine four types of expertise: audit, non-audit accounting, non-accounting financial, and supervisory expertise. We find a negative relation between earnings management and the audit experience of committee members, and that the other types of expertise play no relevant role. We also find that the contribution of audit experts to curbing earnings management proves particularly important in smaller and less active committees, as well as in smaller and busier boards.

(C)2022 ASEPUC. Published by EDITUM - Universidad de Murcia. This is an open access article under the CC BY-NC-ND license (http://creativecommons.org/licenses/by-nc-nd/4.0/).

\section{Competencia del Comité de Auditoría y gestión de los beneficios en Europa} RE S U M EN

Este estudio analiza la asociación entre la competencia de los miembros del Comité de Auditoría y la gestión de los beneficios en una muestra de 142 empresas no financieras de Francia, Alemania, Italia, España y el Reino Unido durante el período 2006-2013. Se mide la competencia de los miembros a través de su dedicación y experiencia. Se descubre que el cargo de consejero externo tiene un efecto doble, de modo que un nivel equilibrado de dedicación al comité de auditoría (aproximadamente dos cargos de consejero externo) reduce la gestión de beneficios. Se examinan igualmente cuatro tipos de experiencia: de auditoría, contable no relacionada con la auditoría, financiera no contable y de supervision, encontrándose una relación negativa entre la gestión de beneficios y la experiencia en auditoría de los miembros del comité, y que los otros tipos de experiencia no desempeñan ningún papel relevante. También se descubre que la contribución de los expertos en auditoría para limitar la gestión de beneficios resulta especialmente importante en los comités más pequeños y menos activos, así como en los consejos más pequeños y más ocupados.

(C)2022 ASEPUC. Publicado por EDITUM - Universidad de Murcia. Este es un artículo Open Access bajo la licencia CC BY-NC-ND (http://creativecommons.org/licenses/by-nc-nd/4.0/). 


\section{Introduction}

The recent financial crisis and high-profile corporate financial scandals have renewed the concerns of policymakers, investors, and academia alike with regard to the quality of financial information Palazuelos Cobo et al., 2017). The reaction of capital market authorities to these episodes has resulted in a more enforceable legal framework. One example of this new framework is the European Union regulatory framework on statutory auditing (mainly, Recommendation 2005/162/EC and Directives 2006/43/EC and 2014/56/EU). This new legal setting focuses on the audit committee and on improving its function by ensuring directors' competence.

Research into these legal changes has shown that, more than the mere existence of audit committees, their monitoring effectiveness and competence are important vis-à-vis enhancing financial reporting quality (Bajra \& Cadez, 2018). These results are in line with the evolution of studies exploring audit committees: whereas the first generation merely addressed the committee's existence, subsequent studies have focused on certain characteristics of such audit committees, particularly their independence, activity and their members' expertise (Biedma López et al., 2011; Bilal et al., 2018; Ghafran \& OŚullivan, 2013; Inaam, 2016; Sultana et al., 2019; Zalata et al., 2018).

Thus, the competence of the committees and their members has emerged as a topic which requires further attention. Whereas US-centred research shows a clear association between the qualifications of the audit committee (in terms of independence, activity, and directors' expertise) and the quality of financial reporting, evidence from outside the US has proven to be less consistent. According to Bilal et al. (2018), the clear results to emerge for American countries may stem from higher institutional transparency, more effective audit committees, and greater investor protection. Given the institutional differences with European countries, a gap emerges in the literature which this research aims to fill.

Although the literature does not provide any explicit definition of director competence, EU Recommendation 2005/162/EC mandates that audit committee directors should possess expertise and that their dedication to the committee must be enough to allow them to perform their duties. In line with this point of view, we posit that the competence of audit committee members depends on two traits: dedication and qualification or expertise. Our first construct is committee member dedication, which provides insights into their ability to spend the time and effort required for them to fulfil their duties on the committee. Our second measure is directors' expertise.

We examine the relation between the qualifications and dedication of audit committee members and earnings management in a sample of 142 European listed firms for the period 2006-2013 from the five largest European Union countries in terms of GDP and stock market capitalization: France, Germany, Italy, Spain, and the United Kingdom. Our time span is prior to the European regulation that includes the concept of audit expertise in the audit committee (Directive 2014/56/EU on Statutory Audits). Up to that point, regulation only considered general accounting expertise in the audit committee. As of 2014, however, the regulatory authorities implicitly admitted that accounting expertise may not be enough and acknowledged the existence of a type of new expertise: audit expertise. Thus, one of our research questions addresses the extent to which the new shift of the European regulatory framework towards specific audit expertise is jus- tified.

We individually examine 1,054 directors, who provide 3,649 director-year observations in order to gauge their experience in four fields: supervisory, financial, audit, and nonaudit accounting expertise. We provide three sets of results. First, a U-shaped relation exists between audit committee members' dedication (in terms of outside directorships) and earnings management. Although multi-directorships may be a good sign of director incentive, a threshold exists (our estimates suggest a maximum of two outside directorships) beyond which too many engagements may prove detrimental. Second, we find that only audit expertise is relevant vis-àvis curbing earnings management and that committees with greater audit experience are negatively related to earnings management. Our third set of results points to certain characteristics of the audit committee, the board, and the firm which enhance the role played by audit experts; namely, smaller or less active audit committees, smaller and busier boards and, in smaller and more profitable firms that have a longerrunning relationship with the external auditor, as well as in firms with smaller and busier boards of directors. Taken together, this evidence suggests that the contribution of audit experts to decreasing earnings management is conditional on the characteristics of the firm and the audit committee.

This paper contributes to the previous literature in three ways. Our first contribution is that we go a step further in order to analyse different types of expertise. Whereas the literature only considers accounting, financial, and supervisory expertise, we underline the importance of audit expertise. Second, we analyse an international sample of European firms, which is by no means a minor issue given the orientation of most prior research. Furthermore, most US-based studies show very strong support for the positive impact of audit committee characteristics on earnings quality, whereas findings from other corporate environments are fragmented and less consistent (Bilal et al., 2018). Thus, we provide additional evidence to support the European-level shift towards better qualified audit committees in the EU. Third, we report the twofold effect of outside commitments. Holding multidirectorships may be positively related to financial reporting quality but becomes detrimental after a given point.

The remainder of the paper is organised as follows. Section 2 provides the literature review and hypotheses development. Section 3 describes the data collection process, the sample, and the research method. Section 4 discusses the results of the empirical analysis, and section 5 summarises the main contributions of the study.

\section{Previous literature and hypothesis development}

In the aftermath of various well-known corporate scandals, the European Parliament created Recommendation 2005/162/CE on the role of non-executive or supervisory directors of listed companies and on-board committees, and Directive 2006/43/CE on statutory audits. In this new legal framework, audit committee members are required to dedicate the necessary time and attention to fulfil their function. Recommendation 2005/162/CE states that directors should limit the number of their other professional commitments, particularly the directorships held in other companies, in order to ensure they can perform their duties properly. European countries have imposed this mandate in different ways (Braiotta \& Zhou, 2008). For instance, France, Germany, and the United Kingdom limit directors to a maximum of four, three, and one directorship, respectively. On 
the other hand, Spain and Italy only require sufficient dedication to the duties involved.

The literature reports both positive and negative effects of multi-directorships. On the positive side, multi-directorships can have a reputation effect, signalling that directors evidence the ability to fulfil their duties. Resource-based theory suggests that directors who sit on multiple boards provide valuable resources that influence corporate decisions. These directors may have richer experience, connections, or expertise that can improve the decision-making process. In this line, prior research shows that, at lower levels, committees containing members who have multiple appointments tend to mitigate discretionary accruals (Dhaliwal et al., 2010; Fich \& Shivdasani, 2006). In addition, directors are interested in preserving their reputation. This motivates them to perform their duties as directors in order to improve the quality of the financial information as an output of the audit committee (Masulis \& Mobbs, 2011; Sharma, 2011). On the negative side, a dedication effect may occur, since belonging to too many boards might harm directors' dedication and negatively affect their work.

Most of the literature confirming this dedication effect has analysed the impact on firm performance, whilst only a few studies have focused on earnings management. This accounting literature echoes the twofold approach, although the results are conditional on the kind of earnings management under consideration (real $v s$. accounting). Thus, while Yang \& Krishnan (2005) find that multiple directorships reduce earnings management, Garven (2015) and Sun et al. (2014) report the opposite results in US firms.

The research has also looked at some emerging countries, yet there is a surprising dearth of studies for Europe (Baccouche et al., 2013; Baccouche \& Omri, 2014). Some examples of these studies that reflect the conflicting results are Baatour et al. (2017) for Arabia, Banderlipe II (2009) for the Philippines, Saleh et al. (2005) and Mansor et al. (2013) for Malaysia, and Sarkar et al. (2008) for India. As far as European countries are concerned, the scant empirical evidence has also failed to provide conclusive results. In this vein, for a sample of French firms, Baccouche \& Omri (2014) find that accumulating several outside directorships by audit committee members leads to a higher degree of earnings management. In contrast, De Vlaminck \& Sarens (2015) report a positive association between the proportion of audit committee members holding more than three directorships and financial statement quality.

Unlike previous research that advocates either a beneficial or a detrimental influence of multi-directorships, we posit that the positive and negative effects of multi-directorships may act in tandem: the reputation effect may initially prevail until the number of directorships reaches a threshold, after which the dedication effect takes over. Our first hypothesis may be broadly stated as follows:

\section{H1: Audit committee members' outside directorships} are related to earnings quality.

Prior literature has examined the role of expertise in the different audit committee functions. Zhang et al. (2007) establish a negative association between financial expertise and weakness in the internal control of US firms. The evidence suggests that audit committees with greater financial expertise are more likely to seek higher levels of external audit (Chen \& Zhou, 2007; Chen et al., 2005), pay higher fees (Vafeas \& Waegelein, 2007; Zaman et al., 2011), and switch from permissible auditor-provided tax services to nonauditor-provided tax services (Albring et al., 2014). For US firms, Bedard et al. (2004) find that audit committee member expertise is negatively associated with aggressive earnings management. Other studies show that expertise is positively correlated with accounting conservatism (Krishnan \& Visvanathan (2008), as well as smaller discretionary current accruals (Xie et al., 2003). Dhaliwal et al. (2010) find for US firms that expertise is positively associated with accruals quality, while Liu et al. (2014) report that US firms with experts on the audit committee exhibit less expectations management and less earnings surprises through expectations management. Abernathy et al. (2013) find that firms with high audit expertise have more accurate and less dispersed earnings forecasts. Using meta-analysis, Bilal et al. (2018), Inaam \& Khamoussi (2016), and Lin \& Hwang (2010) confirm most of these findings.

Although most US-based studies show strong support for the positive impact of audit committee expertise on earnings quality, evidence from non-American firms is not as consistent. Whereas Habbash et al. (2013) fail to find any significant association between financial expertise and absolute discretionary accruals for British firms, Lo et al. (2010) and Siam et al. (2018) report that Chinese and Jordanian firms with financial experts on the audit committee are less likely to manage earnings. De Vlaminck \& Sarens (2015), Piot \& Rémi (2007), and Baxter \& Cotter (2009) find that certain characteristics of audit committee members in Belgian, French, and Australian firms, respectively, are associated with financial statement quality. However, they fail to find any evidence to support the hypothesis related to directors' expertise.

The definition of a financial expert is a key question when examining the influence of expertise, and the varying answers provided in the literature may go some way towards explaining the diverse results (Bilal et al., 2018). Early research identified audit committee expertise with directors who have a corporate or investment banking background (Xie et al., 2003), serve on another audit committee (Karamanou \& Vafeas, 2005), or hold multiple directorships (Baccouche et al., 2013). The Sarbanes-Oxley Act of 2002 provides one of the seminal definitions of financial expert. However, following criticism that the definition was too restrictive, the Securities and Exchange Commission (2003) amended the language so as to embrace the notion that directors can gain expertise through experience supervising employees with financial reporting responsibilities, overseeing the performance of companies, and other relevant experience.

Several studies subsequent to these initial legal definitions sought to measure audit committee member expertise more accurately. Bedard et al. (2004) were among the first to differentiate expertise by type, such as financial expertise and governance expertise. Similarly, Albring et al., (2014) and Zhang et al. (2007) separate financial expertise into accounting and non-accounting expertise, while Hoitash et al. (2009) consider accounting and supervisory financial expertise. As shown by the meta-analysis of Bilal et al. (2018), accounting financial experts have a stronger relationship with earnings quality than non-accounting financial experts. Furthermore, according to Zalata et al. (2018), when financial experts are split by gender, only female financial experts constrain earnings management. Krishnan \& Visvanathan

${ }^{1}$ The US Securities and Exchange Commission defines the concept of financial expert as the person who (i) understands generally accepted accounting principles and financial statements; (ii) has the ability to assess such principles in relation to accounting estimates, provisions, and reserves; (iii) has experience preparing, auditing, analysing, or evaluating financial statements with the same complexity as those expected in their role of director; (iv) understands internal control mechanisms; and (v) understands the functions of the audit committee. 
(2008), Sun et al. (2012), Dhaliwal et al. (2010), and Abernathy et al. (2013) go a step further by categorizing non-financial expertise, in addition to financial accounting and non-accounting expertise. This classification is in line with Badolato et al. (2014) who define three areas of expertise: accounting, supervisory, and finance.

European Directive 2014/56/EU qualifies the minimum competences that audit committees should cover. This Directive is especially relevant because, for the first time, it included audit expertise as a specific skill that directors should possess $^{2}$. Up to that point, the regulation ${ }^{3}$ had only considered general accounting expertise in the audit committee. Member states have also included specific references in their national transpositions. In this vein, Germany requires some knowledge and experience in accounting and auditing. In Spain, at least one director of the audit committee must be appointed considering the member's knowledge and experience in accounting, auditing, or both. Similarly, the European Central Bank (2018) has separated the theoretical experience of decision-makers by distinguishing between accounting and audit experience. Thus, a new dimension of expertise seems to be emerging: audit expertise. This new type of expertise, which differs from accounting expertise, may play a complementary and specific role. Thus, we state our hypothesis concerning the impact of expertise as follows:

H2: Audit committee member audit expertise is positively related to earnings quality.

\section{Empirical design}

\subsection{Sample}

Initially, we identify all the firms listed in the most representative stock exchange indexes in the largest countries of the European Union in terms of GDP and stock market capitalization: France, Germany, Italy, Spain, and the United King$\mathrm{dom}^{4}$ (245 firms). We obtain our final sample by applying several filters to the data so as to ensure the most comprehensive and reliable information possible. We then identify and compile the curricula vitae for all audit committee members in these companies between 2006 and 2013. This information was hand-collected from the firms' annual reports and, where necessary, by looking at other public sources such as Bloomberg Business Week and the official websites of other companies where these directors served.

We then standardise and typify the information on director qualifications included in the curricula vitae. Specifically, we use big data techniques to extract and consolidate all the words related to directors' background, experience, and expertise. ${ }^{5}$ We identify over 600 topics related to academic degrees, work experience, and involvement in public activities. Of these topics, we include university studies; an MA or PhD

\footnotetext{
${ }^{2}$ Paragraph 24 Directive 2014/56/EU mandates that "it is particularly important to reinforce the technical competence of the audit committee by requiring that at least one of its members have competence in auditing and/or accounting".

${ }^{3}$ The members of the audit committee should, collectively, have a recent and relevant background in and experience of finance and accounting for listed companies appropriate to the company's activities. (Recommendation 2005/162/EU)

${ }^{4}$ These indexes are the IBEX-35 (35 Spanish firms), DAX (30 German firms), CAC-40 (40 French firms), FTSE MIB (40 Italian firms), and FTSE100 (100 UK firms).

${ }^{5} \mathrm{Big}$ data techniques are very helpful given the different languages and terms used to express analogous expertise or qualifications such as "auditor," "auditeur," "Prüfer," "revisore," and so on.
}

degree; previous experience as CEO; accounting skills; economic knowledge; previous experience as an external auditor; previous experience as a consultant; activity in politics, diplomacy, or government as a senior officer; and professional experience abroad. We assign a score to each director for each item in order to assess their expertise in different fields. In addition, we examine each director's curriculum vitae so as to obtain the number of outside directorships held in a given year.

We build the final sample by aggregating the information on the audit committee members. In order to ensure data reliability, for a given firm to be included in a given year we require all the information to be available for all the audit committee members in that year. Since not all curricula vitae contain the required data, the number of firms with available information comes down to 142 firms (France, 26; Germany, 24; Italy, 16; Spain, 20, and the United Kingdom, 56) ${ }^{6}$. We complete director-level information with firm-level financial information from the consolidated financial statements from the Bloomberg database.

Table 1. Number of observations and audit committee members by year and country

\begin{tabular}{|c|c|c|c|c|c|c|c|c|c|}
\hline & 2006 & 2007 & 2008 & 2009 & 2010 & 2011 & 2012 & 2013 & Total \\
\hline & \multicolumn{9}{|c|}{ Panel A. Number of observations } \\
\hline France & 15 & 15 & 15 & 15 & 10 & 11 & 24 & 21 & 126 \\
\hline Germany & 15 & 18 & 18 & 22 & 22 & 21 & 24 & 22 & 162 \\
\hline Italy & 12 & 12 & 11 & 13 & 14 & 16 & 14 & 14 & 106 \\
\hline Spain & 11 & 15 & 14 & 16 & 17 & 16 & 16 & 19 & 124 \\
\hline $\begin{array}{l}\text { United } \\
\text { Kingdom }\end{array}$ & 33 & 38 & 40 & 40 & 38 & 28 & 41 & 35 & 293 \\
\hline \multirow[t]{2}{*}{ Total } & 86 & 98 & 98 & 106 & 101 & 92 & 119 & 111 & 811 \\
\hline & \multicolumn{9}{|c|}{ Panel B. Number of audit committee members } \\
\hline France & 57 & 59 & 59 & 62 & 46 & 50 & 105 & 97 & 535 \\
\hline Germany & 77 & 89 & 91 & 116 & 111 & 111 & 124 & 115 & 834 \\
\hline Italy & 66 & 65 & 61 & 77 & 72 & 73 & 68 & 76 & 558 \\
\hline Spain & 43 & 57 & 57 & 64 & 68 & 62 & 64 & 82 & 497 \\
\hline $\begin{array}{l}\text { United } \\
\text { Kingdom }\end{array}$ & 145 & 165 & 165 & 163 & 154 & 112 & 173 & 148 & 1,225 \\
\hline Total & 388 & 435 & 433 & 482 & 451 & 408 & 534 & 518 & 3,649 \\
\hline
\end{tabular}

Panel A (Panel B) provides the number of observations (audit committee members) by year and country.

After this process, we gather a sample of 811 firm-year observations from the 142 firms for the period 2006-2013. Given that our research includes two levels of analysis (firm level and director level), we individually examine the professional information of 1,054 directors who have 3,649 firmyear directorships. Table 1 provides the distribution of the sample by years and countries.

\subsection{Variables}

Consistent with our aim, we operationalize audit committee competence by member dedication and expertise. To some extent the two characteristics are not unrelated because directors serving on other corporate boards can obtain some expertise (Bedard et al., 2004; Bryan et al., 2013). Consequently, we run two separate models for each of the hy-

\footnotetext{
${ }^{6}$ To assess the comprehensiveness of our sample, we compare it with samples from other studies on audit committee expertise such as the 2,484 firm-year observations in Abernathy, et al. (2013), 203 firms in Albring, et al. (2014), the 3,451 firm-year observations in Bedard et al. (2004), 702 directors in DeFond et al. (2005), the 770 firm-year observations in Dhaliwal et al. (2010), the 3,590 firm-year observations in Erkens \& Bonner (2013), the 3,218 audit committee members in Krishnan \& Lee (2009), the 633 firm-year observations in Krishnan \& Visvanathan (2008), the 423 firmyear observations in Kusnadi et al. (2016), and the 98 firms in Sun et al. (2012).
} 
potheses. We use the number of multiple directorships (DIRECTORSHIPS) to assess dedication which, in line with previous research, we measure as the average number of outside boards on which the directors of a given committee sit in the same year (Baccouche et al., 2013; De Vlaminck \& Sarens, 2015; Jiraporn et al., 2008; Jiraporn et al., 2009).

In order to measure director expertise, we compute four kinds of expertise: audit, non-audit accounting, financial, and supervisory (Abernathy et al., 2013; Badolato et al., 2014). We further the work of prior literature on accounting expertise by distinguishing between general (non-audit) accounting expertise and specialised audit expertise. To some extent, this choice has been supported by the European Central Bank (2018), which requires members of the decisionmaking bodies of financial institutions to have differentiated experience in accounting and auditing. Thus, we define ACCOUNT as the proportion of directors on the audit committee who have accounting expertise based on their education (i.e., bachelor, master, or doctoral degree in accounting) or professional background (e.g., certified public accountant, chief financial officer, chief account officer, accountant). Audit expertise (AUDIT) is defined as the proportion of audit committee members who have experience as external auditors or in internal audit departments (Habbash et al., 2013). Financial expertise (FINANCIAL) is defined as the proportion of audit committee members who have held a position in economics, investment banking, chartered financial analysis, or any similar post (DeFond et al., 2005; Zhang et al., 2007). We define supervisory expertise (CEO) as the proportion of audit committee members who have served as a chief executive officer, since it proxies their ability to supervise (Dhaliwal et al., 2010). The translations into English of the terms in several languages (Spanish, Italian, French and German) used to classify the four dimensions of expertise are summarized in Table 2.

Table 2. Identification of each type of expertise

\begin{tabular}{ll}
\hline \multicolumn{1}{c}{$\begin{array}{l}\text { Accountant } \\
\text { Bccounting } \\
\text { Bachelor, master, or doctoral degree in accounting } \\
\text { Certified public accountant } \\
\text { Chief financial officer } \\
\text { Chief account officer }\end{array}$} \\
\hline \multirow{2}{*}{ Audit } & $\begin{array}{l}\text { Audit firms } \\
\text { Chief audit executive } \\
\text { Internal audit departments }\end{array}$ \\
\hline Financial & $\begin{array}{l}\text { Bachelor, master, or doctoral degree in economics } \\
\text { Investment banking } \\
\text { Chartered financial analysis or similar. }\end{array}$ \\
\hline Supervisory & Chief executive officer or similar.
\end{tabular}

Based on these metrics, we also define four dummy variables, ONEAUDIT, ONEACC, ONEFINAN, and ONECEO, which equal 1 when at least one member of the audit committee has audit, non-audit accounting, financial, or supervisory expertise, respectively, and zero otherwise. These variables enable us to check the effectiveness of regulations that require at least one member of the audit committee to be competent in finance, accounting, or auditing.

We also consider a set of control variables due to their potential influence on earnings management. First, we include four board-related variables: audit committee size, directors' power, board size, and board independence. Audit committee size (ACSIZE) is measured by the total number of members on the committee. We define directors' power (POWER) as the proportion of directors with a political, diplomatic, or senior government officer background. This definition is motivated by the prestige and power requirements approach of Pollock et al. (2010), who stress the position of authority within a social organization or institution, and Badolato et al. (2014), who focus on audit committee member status. Board size (BSIZE) is measured by the total number of members on the board. Finally, board independence (INDEP) is measured by the proportion of independent directors within a board. We also control for the tenure of the external auditor (TENURE), measured as the number of years.

Second, we include a number of firm-level financial variables. One of the underlying reasons is to control for the litigation risk (Krishnan \& Krishnan, 1997). Edwards (2019) asserts that expert directors are particularly important when the firm faces risks that are difficult to quantify or measure, but that may result in important losses. Auditor litigation risk is affected by client firm size, the variability of the firm's returns, the receivables, and the inventory, among others ${ }^{7}$. Firm size (ASSET) is calculated as the log of total assets; variability of a firm's returns (VARIAB) is operationalized using the variance of residuals obtained from regressing daily firm stock returns against a market index for a six-month period ${ }^{8}$. RECEIV is the ratio of accounts receivable to total assets; and INVENT is the ratio of inventory to total assets ratio. We also control for financial leverage (LEV) -measured as the ratio of total debt to total assets, profitability (ROA) -the return on assets- firm value (MTB) -the market-to-book ratio-. Finally, we use a set of year and country dummies to control for time and country effects, respectively ${ }^{9}$.

In Table 3, we summarize the main descriptive statistics of all the variables. The mean (median) number of outside directorships of board members is around 1.7 (2). These findings are very similar to those reported by Badolato et al. (2014) for US firms, and slightly lower than those reported by Baccouche et al. (2013) and De Vlaminck \& Sarens (2015) for French and Belgian firms, respectively. Almost all firms (94.8\%) have at least one financial expert on the audit committee. A majority of firms $(83.8 \%)$ have a non-audit accounting expert and a supervisory expert (70\%), and only $30 \%$ of firms have a former auditor on the audit committee. Accounting experts make up $43.8 \%$ of directors. The proportion of ex-auditor directors is around $10 \%$, and the average proportion of directors with financial expertise is $59 \%$. Finally, the mean of directors with CEO experience is $33 \% .^{10}$

Table 4 reports the correlation matrix among the variables. The literature generally considers multicollinearity to be a problem if the correlation between the independent variables is above 0.7 (Cooper \& Schindler, 2003). Although the correlation coefficients are, in general, below 0.7 , we compute the variance inflation factor (VIF) to test the lack of multi-

\footnotetext{
${ }^{7}$ Auditor tenure has also been shown to be related to litigation risk, which confirms the need to control for this issue. The aforementioned authors consider that the receivables and inventory accounts represent an important part of the firm's financial statements, and that there is a high risk for the auditor in this valuation. They also consider that companies which have very variable returns will have a higher probability of losses and, therefore, of legal action against the auditor.

${ }^{8}$ As explained by Stice (1991), the underlying reason is that the higher the variability of a firm's returns, the higher the probability of major decreases and increases in stock price, and the greater the perceived benefit of legal action against the auditor.

${ }^{9}$ We do not include industry dummy variables because we control for industry specific issues when computing discretionary accruals.

${ }^{10}$ These findings are similar to those of prior research. Albring et al. (2014) find that $42 \%$ of directors are accounting experts; Abernathy et al. (2013) report that $14 \%$ of directors are ex-auditors and that $61 \%$ have financial expertise; and Badolato et al. (2014) show that $30 \%$ of directors have CEO experience.
} 
Table 4. Correlation matrix

\begin{tabular}{|c|c|c|c|c|c|c|c|c|c|c|c|c|c|c|c|c|}
\hline \multirow{2}{*}{\multicolumn{17}{|c|}{$\begin{array}{l}\text { (1) DACC } \\
\end{array}$}} \\
\hline & & & & & & & & & & & & & & & & \\
\hline (2) DIRECTORSHIP & -0.020 & & & & & & & & & & & & & & & \\
\hline (3) ACCOUNT & 0.061 & 0.055 & & & & & & & & & & & & & & \\
\hline (4) AUDIT & 0.004 & -0.012 & 0.041 & & & & & & & & & & & & & \\
\hline (5) FINANCIAL & -0.026 & -0.088 & 0.261 & -0.003 & & & & & & & & & & & & \\
\hline (6) CEO & 0.130 & 0.107 & -0.027 & -0.030 & -0.212 & & & & & & & & & & & \\
\hline (7) ACSIZE & -0.066 & 0.175 & -0.060 & 0.087 & 0.052 & -0.240 & & & & & & & & & & \\
\hline (8) ASSET & -0.064 & 0.282 & -0.187 & 0.049 & -0.069 & -0.060 & 0.201 & & & & & & & & & \\
\hline (9) LEV & -0.076 & -0.031 & -0.013 & 0.189 & 0.063 & -0.139 & 0.094 & 0.161 & & & & & & & & \\
\hline (10) ROA & 0.053 & 0.005 & 0.071 & -0.065 & -0.014 & -0.032 & 0.020 & -0.122 & -0.246 & & & & & & & \\
\hline (11) MTB & -0.003 & -0.039 & 0.012 & 0.018 & -0.031 & -0.065 & 0.015 & -0.044 & 0.286 & 0.078 & & & & & & \\
\hline (12) TENURE & 0.128 & 0.072 & -0.004 & -0.069 & -0.191 & 0.101 & -0.016 & 0.003 & -0.125 & -0.005 & -0.025 & & & & & \\
\hline (13) BSIZE & -0.118 & 0.181 & -0.229 & -0.035 & -0.193 & -0.265 & 0.297 & 0.508 & 0.255 & -0.120 & 0.006 & 0.065 & & & & \\
\hline (14) INDEP & 0.076 & 0.105 & 0.004 & -0.059 & -0.108 & 0.271 & 0.069 & 0.146 & -0.210 & 0.017 & -0.044 & 0.061 & -0.254 & & & \\
\hline (15) VARIAB & -0.015 & -0.005 & -0.008 & 0.016 & -0.020 & -0.032 & 0.036 & 0.004 & 0.002 & 0.004 & 0.011 & -0.056 & 0.031 & -0.021 & & \\
\hline (16) RECEIV & -0.049 & -0.022 & 0.039 & 0.015 & -0.031 & -0.074 & 0.027 & -0.230 & 0.120 & 0.006 & -0.019 & 0.029 & 0.076 & -0.099 & -0.041 & \\
\hline (17) INVENT & 0.031 & 0.002 & 0.044 & -0.066 & -0.009 & 0.078 & 0.057 & -0.222 & -0.114 & -0.003 & -0.032 & -0.068 & -0.088 & 0.107 & 0.036 & 0.252 \\
\hline VIF & 1.09 & 1.15 & 1.15 & 1.27 & 1.25 & 1.21 & 1.65 & 1.22 & 1.18 & 1.13 & 1.10 & 1.72 & 1.35 & 1.05 & 1.20 & 1.18 \\
\hline
\end{tabular}

This table provides the pairwise correlation coefficients between the main variables. DACC is the measure of discretionary accruals; DIRECTORSHIP is the average number of outside directorships of board members; ACCOUNT is the proportion of the AC members with non-audit accounting expertise, AUDIT is the proportion of AC members who have experience as an external auditor; FINANCIAL is the proportion of AC members who have previous experience in economics and finance; CEO is the proportion of AC members who have experience as a CEO; ACSIZE is the total number of directors on the audit committee; POWER is the proportion of directors with a political, diplomatic or senior government officer background; ASSET is the logarithm of total sales; LEV is the ratio of total debt to total assets; and ROA is the return on total assets. MTB is the market to book ratio; TENURE is the duration of the relation with the external auditor. BSIZE is the total number of board members; INDEP is the proportion of independent directors on the board; VARIAB is the variability of a firm's return; RECEIV is the accounts receivable to total assets ratio; and INVENT is the inventory to total assets ratio.

Table 3. Descriptive statistics of the main variables

\begin{tabular}{lrcccc}
\hline & Mean & Std. Dev. & Q1 & Median & Q3 \\
\hline DACC & 0.116 & 0.629 & 0.001 & 0.004 & 0.020 \\
DIRECTORSHIPS & 1.748 & 1.119 & 0.000 & 2.000 & 2.333 \\
ACCOUNT & 0.438 & 0.318 & 0.200 & 0.400 & 0.667 \\
AUDIT & 0.078 & 0.130 & 0.000 & 0.000 & 0.200 \\
FINANCIAL & 0.588 & 0.289 & 0.331 & 0.600 & 0.800 \\
CEO & 0.328 & 0.287 & 0.000 & 0.330 & 0.500 \\
ONEACC & 0.838 & 0.368 & 1.000 & 1.000 & 1.000 \\
ONEAUDIT & 0.308 & 0.462 & 0.000 & 0.000 & 1.000 \\
ONEFINAN & 0.948 & 0.221 & 1.000 & 1.000 & 1.000 \\
ONECEO & 0.707 & 0.455 & 0.000 & 1.000 & 1.000 \\
ACSIZE & 4.499 & 1.238 & 4.000 & 4.000 & 5.000 \\
POWER & 0.112 & 0.159 & 0.000 & 0.000 & 0.200 \\
ASSET & 16.685 & 1.203 & 15.833 & 16.751 & 17.542 \\
LEV & 0.660 & 0.153 & 0.553 & 0.677 & 0.770 \\
ROA & 0.114 & 0.070 & 0.082 & 0.112 & 0.143 \\
MTB & 3.947 & 5.735 & 2.251 & 3.141 & 4.430 \\
TENURE & 8.381 & 3.683 & 6 & 9 & 11 \\
BSIZE & 12.928 & 3.625 & 10 & 12 & 15 \\
INDEP & 0.565 & 0.173 & 0.455 & 0.556 & 0.667 \\
VARIAB & 0.010 & 0.068 & 0.0001 & 0.0003 & 0.0005 \\
RECEIV & 0.113 & 0.084 & 0.059 & 0.100 & 0.154 \\
INVENT & 0.072 & 0.064 & 0.015 & 0.059 & 0.115 \\
\hline
\end{tabular}

This table provides the mean, standard deviation, and quartiles of the variables. DACC is the measure of discretionary accruals; DIRECTORSHIPS is the average number of outside directorships of board members; ACCOUNT is the proportion of AC members with accounting expertise; AUDIT is the proportion of audit committee members who have experience as an external auditor; FINANCIAL is the proportion of audit who hite experience comitte the proport ONEAUDI, ONEFINAN, and ONECEO are dummy valables that equal 1 when the $\mathrm{AC}$ has at least one accounting, auditing, finance or supervisory expert, respectively, and that equal zero otherwise; ACSIZE is the total number of directors on the audit committee; POWER is the proportion of directors with a political, diplomatic or senior government official background; ACSIZE is the total number of directors on the audit committee; ASSET is the logarithm of total sales; LEV is the ratio of total debt to total assets; ROA is the return on assets; MTB is the market to book ratio; TENURE is the duration of the relation with the external auditor. BSIZE is the total number of board members; INDEP is the proportion of independent directors on the board; VARIAB is the variability of a firm's return; RECEIV is the accounts receivable to total ass is the variability of a firm's return; RECEIV is the accounts receivable to total assets
ratio; and INVENT is the inventory to total assets ratio. collinearity in our estimates, and we find that VIF values are all below 2 . Given that a lack of multicollinearity is broadly accepted when VIF values are under 5 (Studenmund, 1997), we determine that multicollinearity is not an issue with our sample.

\subsection{Method}

Although the literature has failed to reach any specific conclusion with regard to what earnings quality actually is, evidence from the field points to the importance of earnings management. In their large-scale survey of CFOs, Dichev et al. (2013) underline the prominent role played by earnings management as one of the main factors in firm performance misrepresentation. This focus is in line with the comprehensive survey carried out by Dechow \& Skinner (2000), who provide both academic- and practitioner-related evidence of earnings management. Thus, and keeping in mind that no measure of earnings quality is superior for all decision models, we use accounting earnings management as our measure of earnings quality (Almarayeh et al., 2020; Dechow et al., 2010).

The literature provides a number of accruals models to detect the discretionary component of earnings management. Dechow et al. (2010) review earnings management literature and find that the most commonly used accruals models are the Jones (1991) model, the modified Jones model (Dechow et al., 1995), the Jones model adjusted to ROA (Kothari et al., 2005), and the cash flow model (Dechow \& Dichev, 2002). We compare these accruals models to calculate earnings management.

In order to determine which model has the smallest margin of error, we calculate discretionary accruals based on each of the four models and then apply a specification test and a power test. We base these tests on calculating the number of times that Type I and Type II errors occur for each estimated model, following the method of Brown \& Warner (1985). According to these results, the cash flow model performs better than the other models. We therefore use the performanceadjusted cross-sectional cash flow model (Dechow \& Dichev, 2002). 
Our measure of accruals quality is based on the standard deviation of residuals from firm-specific regressions of changes in working capital accruals on lagged, current, and future cash flows from operations. Operating cash flows are defined as net income adjusted to a cash basis using changes in depreciation, amortization, accounts receivable, and accounts payable. We calculate industry-specific expected accruals using all firms with the same two-digit SIC code, conditional on having at least six year-industry observations with usable data in each SIC group. This model is

$$
\begin{aligned}
\frac{\mathrm{TA}}{\mathrm{A} \mathrm{TA}_{i-1}}= & \frac{\beta_{0}}{\mathrm{~A} \mathrm{TA}_{i-1}}+\beta_{1}\left(\frac{\mathrm{CFO}_{t-1}}{\mathrm{~A} \mathrm{TA}_{i-1}}\right) \\
& +\beta_{2}\left(\frac{\mathrm{CFO}_{t}}{\mathrm{~A} \mathrm{TA}_{i-1}}\right)+\beta_{3}\left(\frac{\mathrm{CFO}_{t+1}}{\mathrm{~A} \mathrm{TA}_{i-1}}\right)+e
\end{aligned}
$$

where TA is total accruals; CFO is the cash-flow from operations; $e$ is the error term, which represents discretionary accruals; and $t$ represents the year. We scale all variables by average total asset (ATA).

As is common in this kind of research, we divide our investigation into two stages. First, we estimate total accruals and compute the discretionary component using equation (1). Second, we analyse the relation between discretionary accruals and our independent variables, with the absolute value of discretionary accruals (DACC) as the dependent variable. Given our assumption that the positive and negative effect of multi-directorships are not mutually exclusive, we test a non-linear relation that introduces both effects simultaneously. The general model is

$$
\begin{aligned}
\text { DACC }_{i, t}= & \beta_{0}+\beta_{1} \text { DIRECTORSHIPS }+\beta_{2} \text { DIRECTORSHIPS } \\
& +\beta_{3} \text { AUDIT }+\beta_{4} \text { FINANCIAL }+\beta_{5} \text { CEO } \\
& +\sum \beta_{i} C V+\mu_{i}+\varepsilon_{i t}
\end{aligned}
$$

where $\beta_{0}$ is the intercept, $\beta_{i}$ is the coefficient of each independent variable, and CV are the control variables. $i$ identifies the individual and $t$ identifies the year; $\mu_{i}$ represents the fixed individual effect; and $\varepsilon_{i t}$, the stochastic error. The stochastic error term combines both the measurement error of any independent variable and the omission of explanatory variables.

Our database combines time-series and cross-sectional data to form panel data. We use the Hausman test to determine whether a fixed effects or random effects estimation model is the most suitable. We verify the assumptions underlying the regression model for all the models and find no problems of multicollinearity and heteroscedasticity. We test for the lack of heteroscedasticity using the Breusch-Pagan or Cook-Weisberg tests.

\section{Results}

Table 5 reports the results on the impact of multiple directorships on earnings management (i.e., the dedication effect). We run a non-linear specification of the model. The negative coefficient of DIRECTORSHIPS and the positive coefficient of DIRECTORSHIPS ${ }^{2}$ confirm a U-shaped relation, with the lowest point being at around two outside board directorships. Our findings thus indicate that serving on less than two boards is related to a reduction in discretionary accruals. The underlying rationale is that economies of scale are in play, such that audit committee member experience on other boards enables them to learn how to work more efficiently. Nevertheless, because directors are charged with carefully controlling the financial information process in the firm, a high number of outside directorships reduces the dedication of directors and thus their ability to monitor the preparation of financial statements. Consistent with Baccouche \& Omri (2014), our results suggest that when audit committee members belong to too many boards, they can become swamped and ineffectively mitigate earnings management. This result corroborates the guideline of the European Central Bank

\begin{tabular}{|c|c|c|}
\hline DIRECTORSHIP & $-1.094 * *$ & $(0.439)$ \\
\hline DIRECTORSHIP2 & $0.290 * *$ & $(0.121)$ \\
\hline POWER & -1.255 & (1.372) \\
\hline ACSIZE & -0.133 & (0.219) \\
\hline ASSET & $1.221^{*}$ & $(0.645)$ \\
\hline LEV & 1.874 & (3.392) \\
\hline ROA & $10.023 * * *$ & (3.563) \\
\hline MTB & 0.173 & $(0.142)$ \\
\hline TENURE & 0.087 & $(0.067)$ \\
\hline BSIZE & $-1.441^{* *}$ & $(0.655)$ \\
\hline BSIZE $^{2}$ & $0.056 * *$ & $(0.025)$ \\
\hline VARIAB & 0.132 & (1.936) \\
\hline RECEIV & $-10.766 * *$ & (4.887) \\
\hline INVENTORY & -0.578 & $(10.093)$ \\
\hline Observations & 618 & \\
\hline Adjusted R-squared & 0.120 & \\
\hline F-test & $3.081^{* * * *}$ & \\
\hline
\end{tabular}
(2018) which advocates limiting the number of directorships that a member of the management body of a financial institution may hold at the same time in different entities.

Table 5. Multiple directorships and discretionary accruals

This table provides the estimated coefficients (standard error) of equation (2). The dependent variable is DACC, a measure of discretionary accruals; DIRECTORSHIP is the average number of outside directorships of board members; POWER is the proportion of directors with a political, diplomatic or senior governmen is the proportion of directors with a political, diplomatic or senior government official background; ACSIZE is the total number of directors on the audit committee; ASSET is the logarithm of total sales; LEV is the ratio of total debt to total assets; ROA is the return on assets; MTB is the market to book ratio; TENURE is the duration of the relation with the external auditor. BSIZE is the total number of board members; INDEP is the proportion of independent directors on the board; VARIAB is the variability of a firm's return; RECEIV is the accounts receivable to total assets ratio; and INVENT is the inventory to total assets ratio. ${ }^{* * *} p$-value $<0.01 .{ }^{* *} p<0.05 .{ }^{*} p<0.10$.

As regards the control variables, the size of the board (BSIZE) also has a U-shaped relationship with abnormal accruals, with the lowest point being reached at around 13 directors. Both the firm's size and performance display a positive and significant coefficient, whereas the receivables coefficient has a negative relationship with earnings management.

We then address the association between directors' expertise (non-audit accounting, audit, financial, and supervisory expertise) and earnings management. Table 6 reports the results. We first run a model in which the dummy variables for the presence of at least one person with each kind of expertise are introduced (Model 1). Accounting, financial, audit, and supervisory expertise are not relevant. Thus, having at least an accounting, CEO, finance expert or former auditor on the audit committee per se does not mean lower earnings management. This result is consistent with Bilal et al. (2018), whose analysis confirms the need to require at least two financial experts in the audit committee. In turn, our results suggest that the legal requirement of having at least one financial or accounting expert does not translate into more reliable financial statements (in terms of earnings management). We then run another analysis with the proportion of 
experts as continuous variables (Model 2 in Table 5). In this model, we simultaneously analyse the four types of expertise. Our results suggest that only audit expertise is relevant to reducing earnings management. Interestingly, our findings show that accounting expertise lacks any significance. This result is in line with Naiker \& Sharma (2009), who also argue that audit experience helps to reduce discretionary accruals. However, accounting (non-audit), financial, and supervisory experience do not mitigate earnings management. The difference between the results with dummy and continuous metrics of expertise has been explained by Bilal et al. (2018), who show that the different measures of audit committee financial expertise moderate the relationship between expertise and earnings quality. In Column 3, we report the results of the model isolating audit experience as a measure of expertise. We have run similar analyses with the other measures of expertise. Given the lack of significance, the results are not tabulated. Model 3 confirms the relevance of audit expertise vis-à-vis reducing earnings management.

Table 6. Directors' expertise and discretionary accruals

\begin{tabular}{|c|c|c|c|}
\hline & (1) & (2) & (3) \\
\hline ONECEO & $0.399(0.337)$ & & \\
\hline ONEACC & $0.095(0.446)$ & & \\
\hline ONEFINAN & $-0.612(0.465)$ & & \\
\hline ONEAUDIT & $0.191(0.142)$ & & \\
\hline CEO & & $-0.958(1.971)$ & \\
\hline ACCOUNT & & $-6.416(12.835)$ & \\
\hline FINANCIAL & & 9.203 (12.534) & \\
\hline AUDIT & & $-6.251 *(3.445)$ & $-6.329 * *(3.100)$ \\
\hline POWER & $-0.565(0.841)$ & $-1.217(2.578)$ & $-2.546(2.184)$ \\
\hline ACSIZE & $0.055(0.121)$ & $0.498(0.386)$ & $0.493(0.359)$ \\
\hline ASSET & $0.061(0.324)$ & $1.751(1.211)$ & $1.383(1.046)$ \\
\hline LEV & -1.309 (1.921) & 0.912 (6.599) & $1.003(5.485)$ \\
\hline ROA & $-1.041(1.630)$ & 6.858 (6.059) & $0.939(5.442)$ \\
\hline MTB & $0.001(0.010)$ & $0.443 *(0.254)$ & $0.013(0.035)$ \\
\hline TENURE & $-0.006(0.038)$ & $0.106(0.127)$ & $0.085(0.111)$ \\
\hline BDSIZE & $0.476(0.434)$ & 0.665 (1.254) & $2.071(1.372)$ \\
\hline BSIZE $^{2}$ & $-0.014(0.016)$ & $-0.026(0.050)$ & $-0.073(0.052)$ \\
\hline INDEP & $-0.355(0.988)$ & $1.138(3.434)$ & 1.650 (3.319) \\
\hline VARIAB & 0.357 (1.375) & $2.059(5.308)$ & $2.801(4.380)$ \\
\hline RECEIV & $-3.948(2.644)$ & $-11.204(9.352)$ & -6.675 (8.959) \\
\hline INVENTORY & $-0.792(5.027)$ & $-0.491(18.294)$ & $-5.077(17.311)$ \\
\hline Observations & 328 & 540 & 529 \\
\hline $\begin{array}{l}\text { Adjusted } \\
\text { R-squared }\end{array}$ & 0.257 & 0.150 & 0.163 \\
\hline F-test & $1.574 * *$ & $2.405 * * *$ & $2.387 * * *$ \\
\hline
\end{tabular}

This table provides the estimated coefficients (standard error) of equation (2). The dependent variable is DACC, a measure of discretionary accruals; ONEACC, ONEAUDIT, ONEFINAN, and ONECEO are dummy variables that equal 1 when the AC has at least accounting, auditing, finance or supervisory expertise, respectively, and that equal zero otherwise; AUDIT is the proportion of audit committee members who have experience as an external auditor; CEO is the proportion of audit committee members who have experience as a CEO; ACCOUNT is the proportion of audit committee members with accounting expertise; FINANCIAL is the proportion of audit committee proportion of directors with a political, diplomatic or senior government official background; ACSIZE is the total number of directors on the audit committee; ASSET is the logarithm of total sales; LEV is the ratio of total debt to total assets; ROA is the return on assets; MTB is the market to book ratio; TENURE is the duration of the relation with the external auditor. BSIZE is the total number of board members; INDEP is the proportion of independent directors on the board; VARIAB is the variability of a firm's return; RECEIV is the accounts receivable to total assets ratio; and INVENT is the inventory to total assets ratio. ${ }^{* * *} p$-value $<0.01 .{ }^{* *} p<0.05 .{ }^{*} p<0.10$

The lack of significance of accounting expertise requires further clarification given prior contradictory evidence, primarily from the United States. Unlike previous research, we analyse accounting expertise and audit expertise separately. Thus, whether the effect of accounting expertise found in other studies is due to audit or non-audit accounting expertise is unknown. We explicitly show that accounting expertise, as it is broadly defined, is too vague and that only audit expertise is relevant in terms of reducing earnings management.

Thus, our evidence for the European argument is not inconsistent with other research in the US environment. For example, DeFond et al. (2005) find a positive market reaction to the appointment of an accounting expert and no relation to the appointment of a non-accounting expert. Dhaliwal et al. (2010) also confirm the non-significant association between accruals quality and finance or CEO expertise on the audit committee. Our result is also consistent with Archambeault \& DeZoort (2001), who argue that not all kinds of expertise in the audit committee are negatively related with suspicious auditor switches.

We now address the question concerning factors which may moderate the association between audit committee expertise and earnings management. Dhaliwal et al. (2010), Krishnan \& Visvanathan (2008), and Bilal et al. (2018) show that some corporate governance characteristics modify the influence of audit experts. We study some characteristics of the audit committee and the board of directors, as well as some financial issues of firms.

As far as corporate governance (board of directors and audit committee) characteristics are concerned, we analyse dedication, size, and activity (Baccouche et al., 2014; DeZoort \& Salterio, 2001; McMullen \& Raghunandan, 1996). We operationalize committee dedication through the proportion of full-time directors, board dedication through the number of outside directorships, size through the number of directors, and activity through the number of meetings.

We divide our sample into two groups depending on the average or median values of these characteristics and replicate the analysis considering audit expertise as the independent variable. Tables 7 and 8 report the results. Thus, in columns $1,3,5,7$, and 9 of Table 7 we report the results for firms with less than the median proportion of full-time committee members, less than the median outside directorships of board members, a number of members below the median, or whose committees meet less than the median. Similarly, in columns 1, 3, and 5 of Table 8 we run analogous models for firms whose size, profitability and auditor tenure are under the sample median value.

Table 7 identifies the characteristics of the board and the committee that enhance the influence of audit expertise. Directors' audit expertise effectively reduces discretionary accruals when the committee has more full-time members (Models 1 and 2). Thus, audit expertise in the committee seems to be catalysed by more dedication from the incumbents. Results for board member dedication are somehow different, which may be explained by the measure of dedication (Models 3 and 4). When dedication to the board is measured through the number of outside directorships, audit expertise becomes more relevant when the directors have less time to spend on a given board.

As far as the committee and board size are concerned, directors with audit knowledge can better apply their skills to reduce discretionary accruals in smaller committees (Models 5 and 6) and smaller boards (Models 7 and 8). This finding is consistent with less human capital in these bodies and, in turn, more valuable input provided by former auditors. It could be said that the contribution of former auditors proves particularly valuable when the input provided by other directors is scarcer.

Models 9 and 10 show a negative association between audit expertise and earnings management in less active audit committees (defined as those holding fewer than six meet- 
Table 7. Director expertise and discretionary accruals

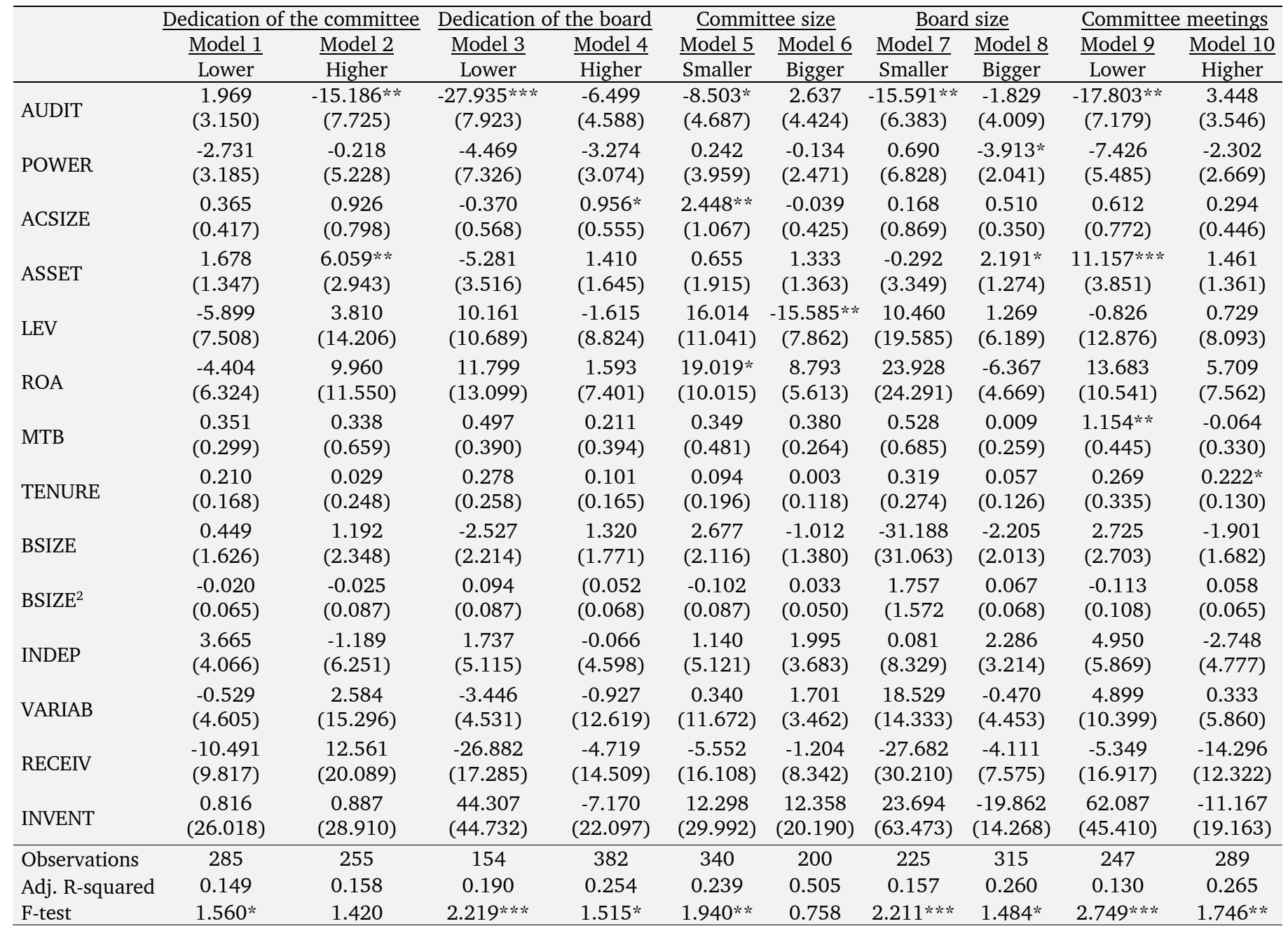

This table provides the estimated coefficients (standard errors) of equation (2). The dependent variable is DACC, a measure of discretionary accruals; AUDIT is the proportion of audit committee members who have experience as an external auditor; POWER is the proportion of directors with a political, diplomatic or senior government official background; ACSIZE is the total number of directors on the audit committee; ASSET is the logarithm of total sales; LEV is the ratio of total debt to total assets; ROA is the return on assets; MTB is the market to book ratio; TENURE is the duration of the relation with the external auditor. BSIZE is the total number of board members; INDEP is the proportion of MTB is the market to book ratio; TENURE is the duration of the relation with the external auditor. BSIZE is the total number of board members; INDEP is the proportion of
independent directors on the board; VARIAB is the variability of a firm's return; RECEIV is the accounts receivable to total assets ratio; and INVENT is the inventory to total assets independent directors on the board; VARIAB is the

ings per year). Although no mandate exists at the European level vis-à-vis audit committee activity, many European countries have issued rules requiring a minimum meeting frequency. ${ }^{11}$ Thus, our findings show that the audit expertise of audit committee members is relevant in less active committees. Taken together, this evidence suggests that the contribution of audit experts to decreasing earnings management is conditional on the characteristics and activity of both the audit committee and the board of directors.

We replicate this analysis considering different scenarios depending on certain firm characteristics (Table 8). We divide our sample into two groups according to the median value of three characteristics: firm size, firm profitability, and external auditor tenure ${ }^{12}$. As regards firm size (Models 1 and 2 ), our findings show that the effect of audit expertise is more important in smaller firms ${ }^{13}$. This result may be due to the fact that the information on large firms is more disperse in the

\footnotetext{
${ }^{11}$ German and Italian committees must meet at least quarterly. In Spain, France, and the United Kingdom, regular meetings are mandatory.

${ }^{12}$ Since the audit tenure is an integer number, in this last case we use the mean value.

${ }^{13}$ The terms "big" and "small" firms must be understood with certain caveats since all the firms in our sample are big enough to be included in the most important stock markets indexes.
}

markets and more available for investors (Siregar \& Utama, 2008).

The impact of audit expertise is also affected by company profitability, such that this expertise only reduces earnings management in the most profitable firms (Columns 3 and 4 of Table 8). This result seems counterintuitive since the managers of the least profitable firms are likely to be under more intense pressure to achieve the expected performance levels. Nevertheless, a more in-depth comparison of both groups of firms show that the most profitable firms have more audit experts in the audit committee ${ }^{14}$. Consequently, this higher proportion of audit experts could increase their power of influence. In Columns 5 and 6, we report the results when the sample is split depending on external auditor tenure. Long auditor tenure may be associated with higher levels of earnings management, since it might lead to a more friendly relationship with managers and so threaten auditor independence (Espinosa-Pike \& Barrainkua, 2016; Gómez Aguilar et al., 2018; González-Díaz et al., 2015; Hohenfels, 2016; Rickett et al., 2016). In such contexts, the specific audit expertise of the directors is especially relevant with regard to mitigating earnings management. We have run similar estimates for

\footnotetext{
${ }^{14}$ The non-tabulated results are available from the authors upon request.
} 
Table 8. Directors' expertise and discretionary accruals

\begin{tabular}{|c|c|c|c|c|c|c|}
\hline & \multicolumn{2}{|c|}{ Firm size } & \multicolumn{2}{|c|}{ Firm profitability } & \multicolumn{2}{|c|}{ Audit tenure } \\
\hline & $\begin{array}{l}\text { Model } 1 \\
\text { Smaller }\end{array}$ & $\begin{array}{c}\text { Model } 2 \\
\text { Bigger }\end{array}$ & $\begin{array}{l}\text { Model } 3 \\
\text { Lower }\end{array}$ & $\begin{array}{c}\text { Model } 4 \\
\text { Higher }\end{array}$ & $\begin{array}{c}\text { Model } 5 \\
\text { Shorter }\end{array}$ & $\begin{array}{c}\text { Model } 6 \\
\text { Longer }\end{array}$ \\
\hline AUDIT & $\begin{array}{l}-9.631 * \\
(5.479)\end{array}$ & $\begin{array}{l}-1.989 \\
(4.195)\end{array}$ & $\begin{array}{c}3.602 \\
(2.775)\end{array}$ & $\begin{array}{c}-21.747 * * * \\
(7.587)\end{array}$ & $\begin{array}{c}-1.594 \\
(3.552)\end{array}$ & $\begin{array}{c}-19.016^{* * * *} \\
(6.820)\end{array}$ \\
\hline POWER & $\begin{array}{c}-0.293 \\
(6.657)\end{array}$ & $\begin{array}{l}-2.546 \\
(2.457)\end{array}$ & $\begin{array}{l}-1.419 \\
(1.857)\end{array}$ & $\begin{array}{c}-4.206 \\
(5.428)\end{array}$ & $\begin{array}{l}-0.601 \\
(1.722)\end{array}$ & $\begin{array}{c}-6.283 \\
(5.026)\end{array}$ \\
\hline ACSIZE & $\begin{array}{c}0.413 \\
(0.676)\end{array}$ & $\begin{array}{c}0.576 \\
(0.426)\end{array}$ & $\begin{array}{c}0.364 \\
(0.324)\end{array}$ & $\begin{array}{c}0.099 \\
(0.779)\end{array}$ & $\begin{array}{c}0.250 \\
(0.254)\end{array}$ & $\begin{array}{c}0.824 \\
(0.844)\end{array}$ \\
\hline ASSET & $\begin{array}{c}5.486 \\
(3.747)\end{array}$ & $\begin{array}{l}3.190 * \\
(1.663)\end{array}$ & $\begin{array}{l}2.052 * \\
(1.174)\end{array}$ & $\begin{array}{c}6.314 \\
(4.190)\end{array}$ & $\begin{array}{c}1.626 \\
(1.361)\end{array}$ & $\begin{array}{l}6.915 * * \\
(2.989)\end{array}$ \\
\hline LEV & $\begin{array}{c}8.175 \\
(13.602)\end{array}$ & $\begin{array}{c}2.085 \\
(7.581)\end{array}$ & $\begin{array}{l}-1.216 \\
(6.150)\end{array}$ & $\begin{array}{c}6.661 \\
(15.980)\end{array}$ & $\begin{array}{l}-0.011 \\
(6.086)\end{array}$ & $\begin{array}{c}1.787 \\
(14.106)\end{array}$ \\
\hline $\mathrm{ROA}$ & $\begin{array}{c}2.487 \\
(11.763)\end{array}$ & $\begin{array}{l}-6.833 \\
(6.988)\end{array}$ & $\begin{array}{c}-20.676 * * * \\
(6.160)\end{array}$ & $\begin{array}{c}29.599 \\
(20.928)\end{array}$ & $\begin{array}{c}3.746 \\
(5.913)\end{array}$ & $\begin{array}{c}-4.595 \\
(11.341)\end{array}$ \\
\hline MTB & $\begin{array}{c}0.576 \\
(0.533)\end{array}$ & $\begin{array}{l}-0.005 \\
(0.315)\end{array}$ & $\begin{array}{c}0.264 \\
(0.195)\end{array}$ & $\begin{array}{c}0.267 \\
(0.527)\end{array}$ & $\begin{array}{l}-0.057 \\
(0.149)\end{array}$ & $\begin{array}{c}0.451 \\
(0.675)\end{array}$ \\
\hline TENURE & $\begin{array}{c}0.197 \\
(0.229)\end{array}$ & $\begin{array}{c}0.088 \\
(0.138)\end{array}$ & $\begin{array}{c}0.086 \\
(0.093)\end{array}$ & $\begin{array}{c}-0.295 \\
(0.326)\end{array}$ & $\begin{array}{c}0.058 \\
(0.083)\end{array}$ & $\begin{array}{l}-0.983 \\
(1.325\end{array}$ \\
\hline BSIZE & $\begin{array}{l}7.797 * * \\
(3.783)\end{array}$ & $\begin{array}{l}-1.276 \\
(1.670)\end{array}$ & $\begin{array}{c}0.824 \\
(1.152)\end{array}$ & $\begin{array}{c}6.450 \\
(4.024)\end{array}$ & $\begin{array}{c}-0.175 \\
(1.287)\end{array}$ & $\begin{array}{c}2.110 \\
(2.771)\end{array}$ \\
\hline BSIZE $^{2}$ & $\begin{array}{l}-0.292 * \\
(0.165)\end{array}$ & $\begin{array}{c}0.037 \\
(0.060)\end{array}$ & $\begin{array}{l}-0.038 \\
(0.042)\end{array}$ & $\begin{array}{c}-0.234 \\
(0.158)\end{array}$ & $\begin{array}{c}0.002 \\
(0.050)\end{array}$ & $\begin{array}{l}-0.065 \\
(0.105)\end{array}$ \\
\hline INDEP & $\begin{array}{l}-0.279 \\
(6.480)\end{array}$ & $\begin{array}{c}2.433 \\
(3.837)\end{array}$ & $\begin{array}{c}2.027 \\
(3.034)\end{array}$ & $\begin{array}{l}-3.657 \\
(6.748)\end{array}$ & $\begin{array}{c}0.960 \\
(2.769)\end{array}$ & $\begin{array}{c}3.346 \\
(6.659)\end{array}$ \\
\hline VARIAB & $\begin{array}{c}8.750 \\
(11.667)\end{array}$ & $\begin{array}{l}-0.624 \\
(4.750)\end{array}$ & $\begin{array}{c}1.233 \\
(3.287)\end{array}$ & $\begin{array}{c}0.754 \\
(17.324)\end{array}$ & $\begin{array}{c}1.153 \\
(2.297)\end{array}$ & $\begin{array}{c}48.208 \\
(219.711)\end{array}$ \\
\hline RECEIV & $\begin{array}{c}-4.931 \\
(20.734)\end{array}$ & $\begin{array}{l}-12.054 \\
(9.892)\end{array}$ & $\begin{array}{c}-5.494 \\
(6.794)\end{array}$ & $\begin{array}{l}-21.671 \\
(27.973)\end{array}$ & $\begin{array}{l}-7.176 \\
(9.349)\end{array}$ & $\begin{array}{c}-0.442 \\
(23.809)\end{array}$ \\
\hline INVENT & $\begin{array}{c}6.969 \\
(42.888)\end{array}$ & $\begin{array}{l}-11.892 \\
(19.508)\end{array}$ & $\begin{array}{c}-1.536 \\
(13.135)\end{array}$ & $\begin{array}{c}6.012 \\
(58.296)\end{array}$ & $\begin{array}{c}-8.850 \\
(11.257)\end{array}$ & $\begin{array}{l}-20.774 \\
(47.616)\end{array}$ \\
\hline Observations & 252 & 252 & 252 & 252 & 238 & 266 \\
\hline Adj. R-squared & 0.188 & 0.137 & 0.213 & 0.256 & 0.596 & 0.263 \\
\hline F-test & $1.87^{* *}$ & 1.34 & $2.34^{* * * k}$ & $2.58^{* * *}$ & 0.690 & $2.266^{\text {*k* }}$ \\
\hline
\end{tabular}

This table provides the estimated coefficients (standard error) of equation (2). The dependent variable is DACC, a measure of discretionary accruals; AUDIT is the proportion of audit committee members who have experience as an external auditor; POWER is the proportion of directors with a political, diplomatic or senior government official background; ACSIZE is the total number of directors on the audit committee; ASSET is the logarithm of total sales; LEV is the ratio of total debt to total assets; ROA is the return on assets; MTB is the market to book ratio; TENURE is the duration of the relation with the external auditor. BSIZE is the total number of board members; INDEP is the proportion of MTB is the market to book ratio; TENURE is the duration of the relation with the external auditor. BSIZE is the total number of board members; INDEP is the proportion of
independent directors on the board; VARIAB is the variability of a firm's return; RECEIV is the accounts receivable to total assets ratio; and INVENT is the inventory to total assets ratio. ${ }^{* * *} p$-value $<0.01 .{ }^{* *} p<0.05 .{ }^{*} p<0.10$.

accounting expertise (ACCOUNT). The results are not tabulated for brevity but do show that such expertise is not significant in many cases. These results corroborate the different role of audit expertise relative to accounting expertise.

Finally, in Table 9 we report the results of the sensitivity analysis. One common concern in this kind of research involves the possible endogeneity of the results. We assume that audit committees are designed to supervise the development and dissemination of reliable financial information (Ghafran \& OŚullivan, 2013). Nevertheless, the characteristics of the audit committee members (i.e., their dedication and experience) might be affected by the quality of financial information, which could result in a problem of endogeneity. We address this issue using two methods: The Generalized Method of Moments (GMM), and Heckman's two-step method. The GMM procedure allows us to address potential endogeneity problems by using the lagged right-hand-side variables as instruments (Blundell \& Bond, 1998). The consistency of GMM estimates depends on both the absence of second-order serial autocorrelation in the residuals and on the validity of the instruments. Thus, in Table 9 we report the Hansen test of over-identifying restrictions and the $\mathrm{m}_{2}$ statistic for the absence of second-order serial correlation in the first-difference residual. The results reported in Columns 1 and 2 corroborate our two basic sets of results: there is a non-linear relationship between the number of outside directorships and earnings management (Column 1), and the proportion of committee members with audit background is negatively related to discretionary accruals (Column 2).

Our second sensitivity analysis is based on the idea of a two-step decision process. First, firms select the audit committee members and, second, the work of these directors affects earnings management. In this case, the Heckman (1979) two-step estimator is a suitable approach (Wooldridge, 2010). This approach involves estimating a probit model for the selection equation, followed by the inclusion of a correctional factor -the inverse Mills ratio calculated from the probit model-. In the second step, an OLS regression model is applied to estimate the relationship between audit committee competence and discretionary accruals. Thus, we define two dummy variables (whether the number of directorships is above the mean value and whether there is a former auditor in the committee), which will be the dependent variables in the first-stage analysis. We then introduce the inverse Mills ratio as an additional independent variable in our models. The results of the second stage are 
reported in Columns 3 and 4 of Table 9, and corroborate the consistency of our baseline estimates.

Table 9. Sensitivity analysis

\begin{tabular}{|c|c|c|c|c|}
\hline & $(1)$ & $(2)$ & (3) & (4) \\
\hline DIRECTORSHIP & $\begin{array}{l}-5.646 * \\
(2.886)\end{array}$ & & $\begin{array}{c}-1.324 * * \\
(0.557)\end{array}$ & \\
\hline DIRECTORSHIP ${ }^{2}$ & $\begin{array}{l}1.846^{*} \\
(0.950)\end{array}$ & & $\begin{array}{l}0.364 * * \\
(0.169)\end{array}$ & \\
\hline AUDIT & & $\begin{array}{c}-34.239 * * \\
(14.910)\end{array}$ & & $\begin{array}{c}-7.193 * * \\
(3.449)\end{array}$ \\
\hline CEO & & $\begin{array}{c}-0.639 \\
(3.423)\end{array}$ & & $\begin{array}{l}-1.482 \\
(1.973)\end{array}$ \\
\hline ACCOUNT & & $\begin{array}{c}9.012 \\
(27.374)\end{array}$ & & $\begin{array}{c}-7.569 \\
(12.773)\end{array}$ \\
\hline FINANCIAL & & $\begin{array}{c}6.899 \\
(25.801)\end{array}$ & & $\begin{array}{c}10.902 \\
(12.485)\end{array}$ \\
\hline POWER & $\begin{array}{c}5.668 \\
(3.912)\end{array}$ & $\begin{array}{c}9.862 \\
(12.131)\end{array}$ & $\begin{array}{l}-1.360 \\
(1.583)\end{array}$ & $\begin{array}{l}-0.589 \\
(2.578)\end{array}$ \\
\hline ACSIZE & $\begin{array}{c}0.165 \\
(0.907)\end{array}$ & $\begin{array}{c}1.431 \\
(1.765)\end{array}$ & $\begin{array}{c}-0.080 \\
(0.269)\end{array}$ & $\begin{array}{c}0.547 \\
(0.385)\end{array}$ \\
\hline ASSET & $\begin{array}{l}1.333^{* *} \\
(0.658)\end{array}$ & $\begin{array}{l}-0.475 \\
(1.533)\end{array}$ & $\begin{array}{c}0.312 \\
(2.007)\end{array}$ & $\begin{array}{c}5.497^{* * * *} \\
(1.990)\end{array}$ \\
\hline LEV & $\begin{array}{l}7.619^{*} \\
(4.203)\end{array}$ & $\begin{array}{c}0.380 \\
(6.764)\end{array}$ & $\begin{array}{c}2.799 \\
(4.769)\end{array}$ & $\begin{array}{c}6.956 \\
(7.043)\end{array}$ \\
\hline ROA & $\begin{array}{l}31.197^{* *} \\
(12.196)\end{array}$ & $\begin{array}{c}12.758 \\
(11.775)\end{array}$ & $\begin{array}{c}4.706 \\
(13.607)\end{array}$ & $\begin{array}{c}104.334 * * \\
(41.664)\end{array}$ \\
\hline MTB & $\begin{array}{c}0.098 \\
(0.278)\end{array}$ & $\begin{array}{c}0.262 \\
(0.473)\end{array}$ & $\begin{array}{c}0.207 \\
(0.187)\end{array}$ & $\begin{array}{c}0.314 \\
(0.259)\end{array}$ \\
\hline TENURE & $\begin{array}{l}0.765 * * \\
(0.322)\end{array}$ & $\begin{array}{l}1.740 * * * \\
(0.531)\end{array}$ & $\begin{array}{c}-0.183 \\
(0.519)\end{array}$ & $\begin{array}{c}0.079 \\
(0.127)\end{array}$ \\
\hline BSIZE & $\begin{array}{l}-1.205 \\
(2.844)\end{array}$ & $\begin{array}{l}-2.439 \\
(4.919)\end{array}$ & $\begin{array}{c}-1.859 * * \\
(0.884)\end{array}$ & $\begin{array}{l}6.508 * * \\
(2.768)\end{array}$ \\
\hline BSIZE $^{2}$ & $\begin{array}{c}0.013 \\
(0.104)\end{array}$ & $\begin{array}{c}0.087 \\
(0.179)\end{array}$ & $\begin{array}{l}0.074 * * \\
(0.037)\end{array}$ & $\begin{array}{c}-0.362^{* * *} \\
(0.151)\end{array}$ \\
\hline INDEP & $\begin{array}{c}2.926 \\
(5.201)\end{array}$ & $\begin{array}{c}41.726 * * * \\
(14.833)\end{array}$ & $\begin{array}{l}-2.411 \\
(4.803)\end{array}$ & $\begin{array}{c}22.584 * * \\
(9.692)\end{array}$ \\
\hline VARIAB & $\begin{array}{l}-9.921 \\
(8.810)\end{array}$ & $\begin{array}{c}15.535 \\
(11.884)\end{array}$ & $\begin{array}{l}-4.866 \\
(9.955)\end{array}$ & $\begin{array}{l}80.201 * * \\
(33.468)\end{array}$ \\
\hline RECEIV & $\begin{array}{c}6.872 \\
(12.385)\end{array}$ & $\begin{array}{c}0.978 \\
(22.795)\end{array}$ & $\begin{array}{l}-8.680 \\
(7.508)\end{array}$ & $\begin{array}{l}64.279 * \\
(33.252)\end{array}$ \\
\hline INVENT & $\begin{array}{l}-10.387 \\
(15.364)\end{array}$ & $\begin{array}{l}43.804 * \\
(25.888)\end{array}$ & $\begin{array}{c}-8.929 \\
(16.319)\end{array}$ & $\begin{array}{l}-28.588 \\
(21.730)\end{array}$ \\
\hline Inverse Mills ratio & & & $\begin{array}{c}8.551 \\
(15.033) \\
\end{array}$ & $\begin{array}{l}41.679 * * \\
(17.628) \\
\end{array}$ \\
\hline Obser & 453 & 31 & 513 & 540 \\
\hline Hansen test ( & $\begin{array}{c}40.17 \\
(51)\end{array}$ & $49.73(41)$ & & \\
\hline & -0.21 & 0.82 & & \\
\hline $\begin{array}{l}\text { Adj. R-squared } \\
\text { F-test }\end{array}$ & & & $\begin{array}{c}0.139 \\
2.746^{* * * *}\end{array}$ & $\begin{array}{c}0.135 \\
2.559^{* * * *}\end{array}$ \\
\hline
\end{tabular}

This table provides the estimated coefficients (standard errors) of Equation 2. The dependent variable is DACC, a measure of discretionary accruals. Columns 1 and 2 report the GMM estimates, and Columns 3 and 4 the Heckman two-step method. DIRECTORSHIP is the average number of outside directorships of board members; AUDIT is the proportion of audit committee members who have experience as an external auditor; CEO is the proportion of audit committee members who have experience as a CEO; ACCOUNT is the proportion of AC members with accounting expertise; FINANCIAL is the proportion of audit committee members who have previous experience in economics and finance; POWER is the proportion of directors with a political, diplomatic or senior government official background; ACSIZE is the total number of directors on the audit committee; ASSET is the logarithm of total total number of directors on the audit committee, ASSET is the logarithm of total is the Levis the ratio of total debt to is the duration of the relation with the is the auditor. BSIZE is the total number

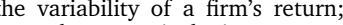
RECEIV is the accounts receivable to total assets ratio; and INVENT is the inventory to total assets ratio. ${ }^{* * *} p$-value $<0.01 .{ }^{* *} p<0.05 .{ }^{*} p<0.10$.

\section{Conclusions}

Prior research around the world highlights the role of the audit committee as one of the key mechanisms of corporate governance with regard to improving the quality and reliability of accounting information. As in other geographical and institutional settings, Europe has made a major effort to create a legal framework aimed at strengthening the proper functioning of such committees. Having ensured committee independence, the new international European framework now seeks to improve committee member competence.

We study the effect on the earnings management of two characteristics related to audit committee competence: committee member dedication and expertise. Whereas previous US-based research shows very strong support for the positive impact of audit committee expertise on earnings quality, evidence from other countries remains scarce, fragmented, and inconsistent. In an attempt to fill this gap, we study a sample of 142 firms from France, Germany, Italy, Spain, and the United Kingdom. Given that our research has two levels of analysis (firm level and director/individual level), we individually examine professional information from 1,054 directors (3,649 director-year observations) between 2006 and 2013, previous to European Directive 2014/56/EU, where the concept of audit expertise is expressly included in the audit commission for the first time. Given that it covers an environment which lacks any mandatory requirement on expertise, this time horizon enables us to test the justifiability of the current legal framework.

We measure directors' dedication with the number of outside directorships. Our results show that these directorships display a U-shaped non-linear relation with earnings management. In turn, although multi-directorships may provide a good signal and incentive, a threshold exists (our estimates suggest around two outside directorships) beyond which too many engagements prevent directors from devoting the necessary time and attention to their duties. As regards expertise, we distinguish four types of experience: specialized audit, general accounting, financial, and supervisory expertise. We find that only specialized audit expertise is relevant in curbing earnings management and that committees with more audit experience are negatively related to earnings management. Furthermore, we find that the requirement for audit committees to have at least one accounting and/or audit expert is not sufficient to reduce earnings management. Our third set of results suggests that certain audit committee characteristics — namely, smaller and less active committees - and board characteristics namely, smaller and busier- enhance the role of audit experts. These results are consistent with the view that audit expertise is more valuable under certain circumstances of scarce resources. The same can be said for some financial characteristics of the firm -smaller, more profitable and with longer external auditor tenure.

Taken together, our results support European authorities' efforts aimed at bolstering audit committee qualifications. Specifically, Directive 2014/56/EU requires at least one audit committee member to have competence in auditing and/or accounting. Our results provide further clarification of this audit versus accounting duality. We find that audit and nonaudit accounting experts fulfil different functions on the audit committee and that audit experts play a more decisive role in curbing earnings management. In addition, we find that having at least one expert on the audit committee does not guarantee the quality of earnings. Thus, although Directive 2014/56/EU is a step in the right direction, it is not 
enough. At present, financial supervisors have taken the lead by requiring the members of financial institution management bodies to report the mandates they hold, including the time and number of meetings dedicated to each mandate (ESMA and EBA, 2018). Similarly, the European Central Bank (2018) has separated the theoretical experience of decision-makers by distinguishing between accounting and audit experience.

Our paper suffers from some limitations that could be addressed in the future. We use the absolute value of abnormal accruals taken from successive balance sheet accounts even though this method could imply some measurement errors compared to when measuring accruals directly from cash flow statements (Hribar \& Collins, 2002). Another limitation of our paper is the sample composition, with British firms accounting for a large proportion of the sample. Although we control for country-level issues, we do not control for the extent to which the European Directive is applied at a national scale.

In addition to these limitations, our study provides several directions for future research. First, since we focus on the foundations of the new legal requirements, one interesting question concerns the extent to which such requirements have been proved to be effective by comparing the influence of audit expertise before and after the enactment of the above-mentioned Directive. Second, directors' dedication could be measured using more fine-grained metrics. While we have used the number of directorships, the time or effort required by each directorship may differ and could somehow be included. Another related direction of research is to explore the specific effect of audit expertise relative to general accounting expertise. Future inquiry should examine what former auditors can bring to the audit committee that accounting experts cannot. Given the importance of reputational risk and trustworthiness standards in the audit industry, our results suggest that former auditors bring considerable value to audit committees. Thus, future research should provide new clues concerning the most effective combinations of expertise.

\section{Acknowledgment}

We thank Ana Zorio (editor), two anonymous referees, and Philip Jaggs for their comments on previous versions of the paper. All the remaining errors are solely the authors' responsibility.

\section{Funding}

This research has received financial support from the Spanish Ministry of Economics, Industry and Competitiveness (ECO2017-84864-P and ECO2015-69637-R).

\section{Conflict of interests}

The authors declare no conflict of interests.

\section{References}

Abernathy, J. L., Herrmann, D., Kang, T., \& Krishnan, G. V. (2013). Audit committee financial expertise and properties of analyst earnings forecasts. Advances in Account- ing, 29(1), 1-11. https://doi.org/10.1016/j.adiac.2012. 12.001

Albring, S., Robinson, D., \& Robinson, M. (2014). Audit committee financial expertise, corporate governance, and the voluntary switch from auditor-provided to non-auditorprovided tax services. Advances in Accounting, 30(1), 8194. https://doi.org/10.1016/j.adiac.2013.12.007

Almarayeh, T. S., Aibar-Guzmán, B., \& Abdullatif, M. (2020). $£$ Influye la calidad de la auditoría en la gestión de resultados en los mercados emergentes? Evidencia de Jordania. Revista de Contabilidad - Spanish Accounting Review, 23(1), 64-74. https://doi.org/10.6018/rcsar.365091

Archambeault, D., \& DeZoort, F. T. (2001). Auditor opinion shopping and the audit committee: An analysis of suspicious auditor switches. International Journal of Auditing, 5, 33-52. https://doi.org/10.1111/1099-1123.00324

Baatour, K., Ben Othman, H., \& Hussainey, K. (2017). The effect of multiple directorships on real and accrual-based earnings management: Evidence from Saudi listed firms. Accounting Research Journal, 30(4), 395-412. https:// doi.org/10.1108/arj-06-2015-0081

Baccouche, S., Hadriche, M., \& Omri, A. (2013). The Impact Of Audit Committee Multiple-Directorships On Earnings Management: Evidence From France. Journal of Applied Business Research, 29(5), 1333-42. https://doi.org/10. 19030/jabr.v29i5.8017

Baccouche, S., Hadriche, M., \& Omri, A. (2014). Multiple directorships and board meeting frequency: evidence from France. Applied Financial Economics, 24(14), 983-92. https://doi.org/10.1080/09603107.2014.920475

Baccouche, S., \& Omri, A. (2014). Multiple directorships of board members and earnings management: An empirical evidence from French listed companies. Journal of Economic and Financial Modelling, 2(1), 13-23

Badolato, P. G., Donelson, D. C., \& Ege, M. (2014). Audit committee financial expertise and earnings management: The role of status. Journal of Accounting and Economics, 58(2), 208-30. https://doi.org/10.1016/j.jacceco.2014. 08.006

Bajra, U., \& Cadez, S. (2018). Audit committees and financial reporting quality: The 8th EU Company Law Directive perspective. Economic Systems, 42(1), 151-63. https://doi.org/10.1016/j.ecosys.2017.03.002

Banderlipe II, M. R. S. (2009). The Impact of Selected Corporate Governance Variables in Mitigating Earnings Management in the Philippines. DLSU Business \& Economics Review, 19(1), 17-27. https://doi.org/10.3860/ber. v19i1.1110

Baxter, P., \& Cotter, J. (2009). Audit committees and earnings quality. Accounting \& Finance, 49(2), 267-90. https:// doi.org/10.1111/j.1467-629X.2008.00290.x

Bedard, J., Chtourou, S. M., \& Courteau, L. (2004). The effect of audit committee expertise, independence, and activity on aggressive earnings management. Auditing: A Journal of Practice \& Theory, 23(2), 13-35. https: //doi.org/10.2308/aud.2004.23.2.13

Biedma López, E., Ruiz Barbadillo, E., \& Gómez Aguilar, N. (2011). £Cómo actúan las empresas frente a la dependencia económica del auditor?: El papel del comité de auditoría. Revista de Contabilidad-Spanish Accounting Review, 14(1), 87-119. https://doi.org/10.1016/ s1138-4891(11)70023-1

Bilal, Chen, S., \& Komal, B. (2018). Audit committee financial expertise and earnings quality: A meta-analysis. Journal of Business Research, 84, 253-70. https://doi. 
org/10.1016/j.jbusres.2017.11.048

Blundell, R., \& Bond, S. (1998). Initial conditions and moment restrictions in dynamic panel data models. Journal of Econometrics, 87(1), 115-43. https://doi.org/10. 1016/S0304-4076(98)00009-8

Braiotta, L., \& Zhou, J. (2008). An exploratory study of the effects of the European Union 8th Directive on Company Law on audit committees: Evidence from EU companies listed on the US stock exchanges. Advances in Accounting, 24(2), 262-71. https://doi.org/10.1016/j. adiac.2008.09.001

Brown, S. J., \& Warner, J. B. (1985). Using daily stock returns: The case of event studies. Journal of Financial Economics, 14(1), 3-31. https://doi.org/10.1016/ 0304-405X(85)90042-X

Bryan, D., Liu, M. C., Tiras, S. L., \& Zhuang, Z. (2013). Optimal versus suboptimal choices of accounting expertise on audit committees and earnings quality. Review of Accounting Studies, 18(4), 1123-58. https://doi.org/10. 1007/s11142-013-9229-8

Cooper, D. R., \& Schindler, P. S. (2003) Research methods. Boston, MA: Irwin.

Chen, K. Y., \& Zhou, J. (2007). Audit committee, board characteristics, and auditor switch decisions by Andersen's clients. Contemporary Accounting Research, 24(4), 1085117. https://doi.org/10.1506/car.24.4.2

Chen, Y. M., Moroney, R., \& Houghton, K. (2005). Audit committee composition and the use of an industry specialist audit firm. Accounting and Finance, 45, 217-39. https://doi.org/10.1111/j.1467-629x.2004.00136.x

De Vlaminck, N., \& Sarens, G. (2015). The relationship between audit committee characteristics and financial statement quality: evidence from Belgium. Journal of Management \& Governance, 19(1), 145-66. https://doi. org/10.1007/s10997-013-9282-5

Dechow, P., Ge, W., \& Schrand, C. (2010). Understanding earnings quality: A review of the proxies, their determinants and their consequences. Journal of Accounting and Economics, 50(2), 344-401. https://doi.org/10.1016/j. jacceco.2010.09.001

Dechow, P. M., \& Dichev, I. D. (2002). The Quality of Accruals and Earnings: The Role of Accrual Estimation Errors. The Accounting Review, 77(S-1), 35-59. https://doi.org/10. 2308/accr.2002.77.s-1.35

Dechow, P. M., \& Skinner, D. J. (2000). Earnings management: Reconciling the views of accounting academics, practitioners, and regulators. Accounting Horizons, 14(2), 235-50. https://doi.org/10.2308/acch.2000.14.2. 235

Dechow, P. M., Sloan, R. G., \& Sweeney, A. (1995). Detecting earnings management. The Accounting Review, 70(2), 193-225.

DeFond, M. L., Hann, R. N., \& Hu, X. (2005). Does the market value financial expertise on audit committees of boards of directors? Journal of Accounting Research, 43(2), 153-93. https://doi.org/10.1111/j.1475-679x. 2005.00166.x

DeZoort, F. T., \& Salterio, S. E. (2001). The effects of corporate governance experience and financial-reporting and audit knowledge on audit committee members' judgments. Auditing: A Journal of Practice \& Theory, 20(2), 31-47. https://doi.org/10.2308/aud.2001.20.2.31

Dhaliwal, D., Naiker, V., \& Navissi, F. (2010). The association between accruals quality and the characteristics of accounting experts and mix of expertise on audit committees. Contemporary Accounting Research, 27(3), 787-
827. https://doi.org/10.1111/j.1911-3846.2010.01027. $\mathrm{x}$

Dichev, I. D., Graham, J. R., Harvey, C. R., \& Rajgopal, S. (2013). Earnings quality: Evidence from the field. Journal of Accounting and Economics, 56(2-3, Supplement 1), 1-33. https://doi.org/10.1016/j.jacceco.2013. 05.004

Edwards, M. (2019). Expert Directors. University of Colorado Law Review, 90, 1051-109.

Erkens, D. H., \& Bonner, S. E. (2013). The role of firm status in appointments of accounting financial experts to audit committees. The Accounting Review, 88(1), 107-36. https://doi.org/10.2308/accr-50261

ESMA and EBA (2018). Guidelines on the assessment of the suitability of members of the management body and key function holders.

Espinosa-Pike, M., \& Barrainkua, I. (2016). An exploratory study of the pressures and ethical dilemmas in the audit conflict. Revista de Contabilidad-Spanish Accounting Review, 19(1), 10-20. https://doi.org/10.1016/j. rcsar.2014.10.001

European Central Bank (2018). Guide to fit and proper assessments. Frankfurt.

Fich, E. M., \& Shivdasani, A. (2006). Are busy boards effective monitors? Journal of Finance, 61(2), 689-724. https://doi.org/10.1111/j.1540-6261.2006.00852.x

Garven, S. (2015). The effects of board and audit committee characteristics on real earnings management: Do boards and audit committees play a role in its promotion or constraint? Academy of Accounting and Financial Studies Journal, 19(1), 67-84.

Ghafran, C., \& O'Sullivan, N. (2013). The governance role of audit committees: reviewing a decade of evidence. International Journal of Management Reviews, 15(4), 381407. https://doi.org/10.1111/j.1468-2370.2012.00347. $\mathrm{x}$

Gómez Aguilar, N., Biedma Lopez, E., \& Ruiz Barbadillo, E. (2018). The effect of audit partner rotation on audit quality. Revista de Contabilidad-Spanish Accounting Review, 21(1), 7-18. https://doi.org/10.1016/j.rcsar.2017. 03.001

González-Díaz, B., García-Fernández, R., \& López-Díaz, A. (2015). Auditor tenure and audit quality in Spanish stateowned foundations. Revista de Contabilidad-Spanish Accounting Review, 18(2), 115-26. https://doi.org/10. 1016/j.rcsar.2014.04.001

Habbash, M., Sindezingue, C., \& Salama, A. (2013). The effect of audit committee characteristics on earnings management: Evidence from the United Kingdom. International Journal of Disclosure and Governance, 10(1), 1338. https://doi.org/10.1057/jdg.2012.2

Heckman, J. (1979). Sample selection bias as a specification error. Econometrica, 47(1), 153-61.

Hohenfels, D. (2016). Auditor tenure and perceived earnings quality. International Journal of Auditing, 20(3), 224-38. https://doi.org/10.1111/ijau.12069

Hoitash, U., Hoitash, R., \& Bedard, J. C. (2009). Corporate governance and internal control over financial reporting: A comparison of regulatory regimes. The Accounting Review, 84(3), 839-67. https://doi.org/10.2308/accr.2009. 84.3.839

Hribar, P., \& Collins, D. W. (2002). Errors in estimating accruals: Implications for empirical research. Journal of Accounting Research, 40(1), 105-34. https://doi.org/10. 1111/1475-679X.00041

Inaam, Z. (2016). Audit committee effectiveness, audit qual- 
ity and earnings management: a meta-analysis. International Journal of Law and Management, 58(2), 179-96. https://doi.org/10.1108/ijlma-01-2015-0006

Inaam, Z., \& Khamoussi, H. (2016). Audit committee effectiveness, audit quality and earnings management: a meta-analysis. International Journal of Law and Management, 58(2), 179-96. https://doi.org/10.1108/ IJLMA-01-2015-0006

Jiraporn, P., Sang-Kim, Y., \& Davidson III, W. N. (2008). Multiple Directorships and Corporate Diversification. Journal of Empirical Finance, 15, 418-35. https://doi.org/10. 1016/j.jempfin.2007.07.002

Jiraporn, P., Singh, M., \& Lee, C. I. (2009). Ineffective corporate governance: Director busyness and board committee memberships. Journal of Banking \& Finance, 33, 819-28. https://doi.org/10.1016/j.jbankfin.2008.09.020

Jones, J. J. (1991). Earnings management during import relief investigations. Journal of Accounting Research, 29(2), 193-228. https://doi.org/10.2307/2491047

Karamanou, I., \& Vafeas, N. (2005). The association between corporate boards, audit. committees, and management earnings forecasts: An empirical analysis. Journal of Accounting Research, 43(3), 453-86. https://doi.org/10. 1111/j.1475-679X.2005.00177.x

Kothari, S. P., Leone, A. J., \& Wasley, C. E. (2005). Performance matched discretionary accrual measures. Journal of Accounting and Economics, 39(1), 163-97. https://doi. org/10.1016/j.jacceco.2004.11.002

Krishnan, G. V., \& Visvanathan, G. (2008). Does the SOX definition of an accounting expert matter? The association between audit committee directors' accounting expertise and accounting conservatism. Contemporary Accounting Research, 25(3), 827-58. https://doi.org/10. 1506/car.25.3.7

Krishnan, J., \& Krishnan, J. (1997). Litigation risk and auditor resignations. Accounting Review, 539-60.

Krishnan, J., \& Lee, J. E. (2009). Audit committee financial expertise, litigation risk, and corporate governance. Auditing: A Journal of Practice \& Theory, 28(1), 241-61. https://doi.org/10.2308/aud.2009.28.1.241

Kusnadi, Y., Leong, K. S., Suwardy, T., \& Wang, J. (2016). Audit Committees and Financial Reporting Quality in Singapore. Journal of Business Ethics, 139(1), 197-214. https://doi.org/10.1007/s10551-015-2679-0

Lin, J. W., \& Hwang, M. I. (2010). Audit quality, corporate governance, and earnings management: A meta-analysis. International Journal of Auditing, 14(1), 57-77. https: //doi.org/10.1111/j.1099-1123.2009.00403.x

Liu, M. H. C., Tiras, S. L., \& Zhuang, Z. (2014). Audit committee accounting expertise, expectations management, and nonnegative earnings surprises. Journal of Accounting and Public Policy, 33(2), 145-66. https://doi.org/10. 1016/j.jaccpubpol.2013.12.004

Lo, A. W. Y., Wong, R. M. K., \& Firth, M. (2010). Can corporate governance deter management from manipulating earnings? Evidence from related-party sales transactions in China. Journal of Corporate Finance, 16(2), 225-35. https://doi.org/10.1016/j.jcorpfin.2009.11.002

Mansor, N., Che Ahmad, A., Ahmad-Zaluki, N. A., \& Osman, A. H. (2013). Corporate governance and earnings management: A study on the Malaysian family and non-family owned PLCs. Procedia Economics and Finance, 7, 221-29. https://doi.org/10.1016/S2212-5671(13)00238-4

Masulis, R. W., \& Mobbs, S. (2011). Are all inside directors the same? Evidence from the external directorship market. Journal of Finance, 66(3), 823-72. https://doi.org/ 10.1111/j.1540-6261.2011.01653.x

McMullen, D. A., \& Raghunandan, K. (1996). Enhancing audit committee effectiveness. Journal of Accountancy, 182(2), 79-81.

Naiker, V., \& Sharma, D. S. (2009). Former audit partners on the audit committee and internal control deficiencies. The Accounting Review, 84(2), 559-87. https://doi.org/ 10.2308/accr.2009.84.2.559

Palazuelos Cobo, E., Montoya del Corte, J., \& Herrero Crespo, Á. (2017). Determinantes de la continuidad en la contratación de la auditoría de forma voluntaria: evidencia para el caso de España. Revista de Contabilidad-Spanish Accounting Review, 20(1), 63-72. https://doi.org/10. 1016/j.rcsar.2016.06.001

Piot, C., \& Rémi, J. (2007). External Auditors, Audit Committees and Earnings Management in France. European Accounting Review, 16(2), 429 - 54. https://doi.org/10. 1080/09638180701391030

Pollock, T. G., Chen, G., Jackson, E. M., \& Hambrick, D. C. (2010). How much prestige is enough? Assessing the value of multiple types of high-status affiliates for young firms. Journal of Business Venturing, 25(1), 6-23. https: //doi.org/10.1016/j.jbusvent.2009.01.003

Rickett, L. K., Maggina, A., \& Alam, P. (2016). Auditor tenure and accounting conservatism: evidence from Greece. Managerial Auditing Journal, 31(6-7), 538-65. https: //doi.org/10.1108/MAJ-10-2014-1103

Saleh, N. M., Iskandar, T. M., \& Rahmat, M. M. (2005). Earnings management and board characteristics: Evidence from Malaysia. Jurnal Pengurusan (UKM Journal of Management), 24, 77-103

Sarkar, J., Sarkar, S., \& Sen, K. (2008). Board of Directors and Opportunistic Earnings Management: Evidence from India. Journal of Accounting, Auditing \& Finance, 23(4), 517-51. https://doi.org/10.1177/ $0148558 \times 0802300405$

Securities and Exchange Commission (2003). Disclosure Required by Sections 406 and 407 of the Sarbanes-Oxley Act of 2002. Release Nos. 33-8177, 34-47235. Washington: SEC.

Sharma, V. (2011). Independent directors and the propensity to pay dividends. Journal of Corporate Finance, 17, 100115. https://doi.org/10.1016/j.jcorpfin.2011.05.003

Siam, Y. A., Idris, M., \& Al-Okdeh, S. (2018). The Moderating Role of Family Control on the Relationship between Audit Committee Financial Expertise and Earnings Management. International Journal of Business and Management, 13(12), 31-37. https://doi.org/10.5539/ijbm. v13n12p31

Siregar, S. V., \& Utama, S. (2008). Type of earnings management and the effect of ownership structure, firm size, and corporate-governance practices: Evidence from Indonesia. The International Journal of Accounting, 43, 1-27. https://doi.org/10.1016/j.intacc.2008.01.001

Stice, J. D. (1991). Using financial and market information to identify pre-engagement factors associated with lawsuits against auditors. Accounting Review, 66(3), 516-33.

Studenmund, A. H. (1997) Using Econometrics: A Practical Approach. Boston: Addison-Wesley.

Sultana, N., Singh, H., \& Rahman, A. (2019). Experience of Audit Committee Members and Audit Quality. European Accounting Review, 28(5), 947-75. https://doi.org/10. 1080/09638180.2019.1569543

Sun, F., Wei, X., \& Xu, Y. (2012). Audit committee characteristics and loss reserve error. Managerial Auditing Journal, 27(4), 355-77. https://doi.org/10.1108/ 
02686901211217978

Sun, J., Lan, G., \& Liu, G. (2014). Independent audit committee characteristics and real earnings management. Managerial Auditing Journal, 29(2), 153-72. https://doi.org/ 10.1108/maj-05-2013-0865

Vafeas, N., \& Waegelein, J. F. (2007). The association between audit committees, compensation incentives, and corporate audit fees. Review of Quantitative Finance and Accounting, 28(3), 241-55. https://doi.org/10.1007/ s11156-006-0012-9

Wooldridge, J. M. (2010) Econometric analysis of cross section and panel data. Cambridge, Massachusetts, USA: MIT Press.

Xie, B., Davidson, W. N., \& Dadalt, P. J. (2003). Earnings management and corporate governance: the role of the board and the audit committee. Journal of Corporate Finance, 9, 295-316. https://doi.org/10.1016/S0929-1199(02) 00006-8

Yang, J. S., \& Krishnan, J. (2005). Audit committees and quarterly earnings management. International Journal of Auditing, 9(3), 201-19. https://doi.org/10.1111/j. 1099-1123.2005.00278.x

Zalata, A. M., Tauringana, V., \& Tingbani, I. (2018). Audit committee financial expertise, gender, and earnings management: Does gender of the financial expert matter? International Review of Financial Analysis, 55, 170-83. https://doi.org/10.1016/j.irfa.2017.11.002

Zaman, M., Hudaib, M., \& Haniffa, R. (2011). Corporate governance quality, audit fees and non-audit services fees. Journal of Business Finance \& Accounting, 38(1-2), 16597. doi.

Zhang, Y., Zhou, J., \& Zhou, N. (2007). Audit committee quality, auditor independence, and internal control weaknesses. Journal of Accounting and Public Policy, 26(3), 300-27. https://doi.org/10.1016/j.jaccpubpol.2007.03. 001 